\title{
Chemical Composition of Drilled Wells Water for Ruminants
}

\author{
Daniel Bomfim Manera ${ }^{1}$, Tadeu Vinhas Voltolini ${ }^{2}$, Daniel Ribeiro Menezes ${ }^{1} \&$ Gherman Garcia Leal de Araújo ${ }^{2}$ \\ ${ }^{1}$ Universidade Federal do Vale do São Francisco (Univasf), Petrolina/PE, Brazil \\ ${ }^{2}$ Embrapa Semiárido, Petrolina/PE, Brazil \\ Correspondence: Tadeu Vinhas Voltolini, Embrapa Semiárido, BR 428, Km 152, Zona rural, CEP 56302-210, \\ Petrolina/PE, Brazil. Tel: 87-3866-3657. E-mail: tadeu.voltolini@embrapa.br
}

Received: January 12, 2016

Accepted: August 20, $2016 \quad$ Online Published: November 15, 2016

doi:10.5539/jas.v8n12p127

URL: http://dx.doi.org/10.5539/jas.v8n12p127

\begin{abstract}
This study aimed to evaluate the chemical composition of water wells and to discuss the results in relation to nutritional requirements and tolerance limits of domestic ruminants. Ten samples of water wells (three replicates) from Brazilian semi-arid were collected and analyzed for their macro and trace minerals levels. A variation was found in the mineral composition of the waters and the macro minerals presenting highest levels were $\mathrm{Cl}, \mathrm{Mg}$, $\mathrm{Ca}$ and $\mathrm{Na}$, while the predominant trace minerals were $\mathrm{Fe}$ and $\mathrm{Mn}$. The concentration of the examined minerals can provide a small contribution to the animal as in the case of $\mathrm{P}$ or supply a considerable amount as $\mathrm{Cl}$. The levels of total dissolved solids found in the majority of the samples can be tolerable for ruminants. In some of the samples the presence of $\mathrm{Pb}, \mathrm{Cd}$ and $\mathrm{Cr}$ was found in concentrations higher than the upper recommended limit for ruminants.
\end{abstract}

Keywords: heavy metals, trace minerals, water source

\section{Introduction}

Water is a vital nutrient for all human beings and is considered a scarce resource in several regions in the world. In arid and semi-arid regions, animal production present great social and economic importance, where water availability constitutes one of the greatest challenges (Araújo et al., 2010).

Apart from water volumes, Beede (2012) points out that qualitative water parameters are important for the livestock production systems. Valtorta et al. (2008), Arjomandfar et al. (2010) and Visscher et al. (2013) report that ruminants can tolerate and accept water showing considerable salts concentration.

In addition, Brum and Sousa (1985) indicate that water can be an important source of mineral for ruminants. Minerals are important to grazing and feedlot animals as cattle, sheep and goats, and their deficiency may cause nutritional (Herdt \& Hoff, 2011), reproductive (Mendonça Junior et al., 2011) and productive disorders (Tokarnia et al., 1999).

At the NRC (2001), it was also pointed out how important it is to observe the presence of minerals potentially toxic in the water such as $\mathrm{Pb}$ and $\mathrm{Cd}$ in order to avoid the supply to the animals. Cadmium and $\mathrm{Pb}$ are elements considered toxic to animals, which may accumulate in the body (Pareja-Carrera et al., 2014).

In the Brazilian semi-arid, subsurface waters can be an important source for the herds, especially from tube wells, but the physical-chemical composition of total dissolved solids (TDS), macro and trace minerals is scarce. On the other hand, it is important to understand the potential of water to be offered to animals and to propose measures to watering ruminants.

The objective was to examine the mineral composition of well water in the Brazilian semi-arid and to discuss the results based on the nutritional requirements and tolerance levels of ruminants.

\section{Materials and Methods}

This study lasted from March 2011 to March 2012. Water samples were collected from drilled wells in the Brazilian semi-arid in the municipalities of Jaguarari, Santa Brígida and Pintadas, in Bahia State; Lagoa Grande and Petrolina, in Pernambuco State; and Tauá, in Ceará State, Brazil. We collected ten samples of drilled wells water, with three replicates. 
The mineral composition of all samples was determined at the Soil Laboratory of Embrapa Semiárido. The concentrations of potassium $(\mathrm{K})$, phosphorus $(\mathrm{P})$, calcium $(\mathrm{Ca})$, magnesium $(\mathrm{Mg})$, sulfur $(\mathrm{S})$, copper $(\mathrm{Cu})$, iron $(\mathrm{Fe})$, manganese $(\mathrm{Mn})$, zinc $(\mathrm{Zn})$, sodium $(\mathrm{Na})$, chlorine $(\mathrm{Cl})$, nickel $(\mathrm{Ni})$, lead $(\mathrm{Pb})$, cadmium $(\mathrm{Cd})$ and chromium (Cr) were determined according to the methodologies described by Nogueira et al. (2005). The concentrations of the minerals present in the water were obtained as $\mathrm{mg} / \mathrm{L}$.

Sodium and potassium levels were determined by flame photometry, whereas the concentrations of $\mathrm{Ca}$ and $\mathrm{Mg}$ were analyzed by titration, by determining the $\mathrm{Ca}$ contents, and subsequently the $\mathrm{Ca}+\mathrm{Mg}$ contents, and the $\mathrm{Mg}$ concentration was defined as the difference. Chlorine and sulfur levels were determined indirectly, first by obtaining the concentrations of chlorines and sulfates and subsequently, by considering the atomic molecular weight, the concentrations of $\mathrm{S}$ and $\mathrm{Cl}$ were determined.

Phosphorus was determined using a molecular spectrophotometer while the determination of $\mathrm{Cu}, \mathrm{Fe}, \mathrm{Mn}, \mathrm{Zn}, \mathrm{Ni}$, $\mathrm{Pb}, \mathrm{Cd}$ and $\mathrm{Cr}$ was performed on an atomic absorption spectrophotometer (model Analyst 100, Perkin Elmer ${ }^{\circledR}$ ). The data were presented as descriptive statistics (means and standard deviations).

\section{Results and Discussion}

The average macro mineral found in greater concentrations were $\mathrm{Cl}, \mathrm{Mg}, \mathrm{Ca}$ and $\mathrm{Na}$ with 1.010, 270, 240 and 230 $\mathrm{mg} / \mathrm{L}$, respectively. Chlorine was also the element with highest variation: from 430 to $2.580 \mathrm{~g} / \mathrm{L}$. The average of S was $100 \mathrm{mg} / \mathrm{L}$, whereas $\mathrm{K}$ was $10 \mathrm{mg} / \mathrm{L}$. Phosphorus content was found at very low concentration, at the order of $80 \mathrm{mg} / \mathrm{L}$ (Table 1).

The sum of macro and trace minerals, on average, was $1.940 \mathrm{mg} / \mathrm{L}(1.94 \mathrm{~g} / \mathrm{L})$ ranging from 750 to $4.660 \mathrm{mg} / \mathrm{L}$. According to Brazilian legislation lesser than $0.5 \mathrm{~g} / \mathrm{L}(500 \mathrm{mg} / \mathrm{L})$ of total dissolved solids (TDS), in the water, is considered fresh, between $0.5 \mathrm{~g} / \mathrm{L}$ to $30 \mathrm{~g} / \mathrm{L}$ are classified as brackish and with more than $30 \mathrm{~g} / \mathrm{L}$ are saline (CONAMA, 2005). Oliveira and Maia (1998) examined the physical and chemical composition of waters from different aquifers in the state of Rio Grande do Norte, (496 samples from water wells, 129 samples from subsurface waters) and observed 0.8 to $4.0 \mathrm{dS} / \mathrm{m}$ of electrical conductivity, equivalent to 510 to $2.560 \mathrm{mg} / \mathrm{L}$ of TDS, with 1.0 $\mathrm{dS} / \mathrm{m}=640 \mathrm{mg} / \mathrm{L}$.

Nine of the ten samples found in the current study showed TDS levels that were within the limits proposed by Beede (2012), which are $3.000 \mathrm{mg} / \mathrm{L}$, in order to avoid problems to the animals. Kattnig et al. (1992), Bahman et al. (1993), Valtorta et al. (2008), and Arjomandfar et al. (2010) examined the productive response of bovines receiving water containing high TDS levels, over $1.400 \mathrm{mg} / \mathrm{L}$ and observed no negative effect on productive response. Valtorta et al. (2008) observed an increase in water intake with $10.000 \mathrm{mg} / \mathrm{L}$ of TDS, which was also observed by Visscher et al. (2013) when studying the tolerance of bulls receiving saline water with 100, 5.000 or $10.000 \mathrm{mg} / \mathrm{L}$ of a $\mathrm{NaC} 1$ and $\mathrm{KCl}$ mixture.

According to McGregor (2004) bovines can also tolerate waters containing 2.300 to $11.000 \mathrm{mg} / \mathrm{L}$ of TDS, however, the author points out the necessity of adapting animals to saline water as an important factor to improve their tolerance. Abou Hussein et al. (1994) examined increased salinity up to $17.000 \mathrm{mg} / \mathrm{L}$ of TDS of total water intake of goats and sheep. Increased salt content from 9.500 to $17.000 \mathrm{mg} / \mathrm{L}$ of TDS reduced feed intake of both sheep and goats. Water intake with $9.500 \mathrm{mg} / \mathrm{L}$ of TDS reduced the feed intake of sheep but not of goats. 
Table 1. Macro mineral concentration $(\mathrm{mg} / \mathrm{L})$ of the water from drilled wells in the Brazilian semi-arid

\begin{tabular}{lllllllll}
\hline Sample & $\mathrm{P}$ & $\mathrm{K}$ & $\mathrm{Ca}$ & $\mathrm{Mg}$ & $\mathrm{S}$ & $\mathrm{Na}$ & $\mathrm{Cl}$ & $\mathrm{TDS}$ \\
\hline 1 & 30 & 10 & 210 & 80 & 80 & 120 & 430 & 960 \\
2 & $-*$ & 10 & 200 & 180 & 160 & 220 & 740 & 1,510 \\
3 & $-*$ & 20 & 220 & 540 & 200 & 180 & 1,430 & 2,590 \\
4 & 250 & 20 & 160 & 290 & 40 & 220 & 1,060 & 2,040 \\
5 & 10 & 20 & 510 & 660 & 120 & 760 & 2,580 & 4,660 \\
6 & 40 & 10 & 180 & 130 & 110 & 260 & 740 & 1,470 \\
7 & 140 & 20 & 450 & 140 & 70 & 140 & 670 & 1,630 \\
8 & $-*$ & 20 & 170 & 200 & 100 & 160 & 770 & 1,420 \\
9 & 90 & 20 & 190 & 420 & 60 & 130 & 1,360 & 2,270 \\
10 & 60 & 10 & 110 & 80 & 80 & 60 & 350 & 750 \\
- Mean $^{-10}$ & 80 & 10 & 240 & 270 & 100 & 230 & 1,010 & 1,930 \\
SD & 80 & 10 & 130 & 200 & 50 & 200 & 650 & 1,110 \\
Guidelines & 0.70 & 20 & 200 & 100 & -1 & 300 & -1 & 3,000 \\
Guidelines & $-{ }^{\mathrm{b}}$ & -1 & $>500$ & $>125$ & -1 & $>20$ & -1 & $>3,000$ \\
\hline
\end{tabular}

Note. $\mathrm{P}^{*}=$ phosphorus $(\mathrm{mg} / \mathrm{L}) ; \mathrm{K}=$ potassium; $\mathrm{Ca}=$ calcium; $\mathrm{Mg}=$ magnesium; $\mathrm{S}=$ sulfur $; \mathrm{Na}=$ sodium; $\mathrm{Cl}=$ chlorine; $\mathrm{SD}=$ standard deviation; TDS = total dissolved solids (macro and trace mineral sum); ${ }^{\mathrm{a}, \mathrm{b}}$ Beede (2012) $\left({ }^{\mathrm{a}}\right.$ : concentrations above which problems likely could occur in livestock; ${ }^{\mathrm{b}}:$ possible cattle problems); ${ }^{1}:$ non presented; * = non detected.

According to NRC (2001), TDS concentrations below $1.000 \mathrm{mg} / \mathrm{L}$ are considered safe in the bovine drinking water. Concentrations from $1.000 \mathrm{mg} / \mathrm{L}$ to $2.999 \mathrm{mg} / \mathrm{L}$ are generally considered safe, but may cause diarrhea in animals that are not adapted to these hydric sources. Water containing $4.600 \mathrm{mg} / \mathrm{L}$ of TDS may be rejected by the animals without previous experience, cause diarrhea or reduce productivity compared to the waters with lower TDS. Waters with 5.000 to $6.999 \mathrm{mg} / \mathrm{L}$ of TDS should be avoided by pregnant or lactating animals while waters with more than $7.000 \mathrm{mg} / \mathrm{L}$ should not be offered to cows (NRC, 2001).

Domestic ruminants have been used and accepted saline waters with considerable TDS levels (Valtorta et al., 2008; Arjomandfar et al., 2010), but there are differences among the species as to their tolerance. Masters et al. (2007) reported the order in which animals are tolerant to salinity as camels $>$ sheep $>$ goats $>$ cattle. In studies conducted in the Brazilian semi-arid with cows and goats that ingest waters with 650 to $8.960 \mathrm{mg} / \mathrm{L}$, it was also observed that ruminants accepted and tolerated waters of up to $8.960 \mathrm{mg} / \mathrm{L}$ of TDS (Albuquerque, 2012; Alves, 2012; Costa, 2012).

Costa (2012) did not find differences in productive performance of sheep, nor in intake and digestibility of DM and nutrients (neutral detergent fiber, crude protein, total carbohydrates and total digestible nutrients) when they were exposed to waters with $5.760 \mathrm{mg} / \mathrm{L}$ of TDS, superior to their found in the water of drilled wells in the current study.

Tolerance to saline water is also related to the different physiological stages of the animal (Squires, 1993; NRC, 2001), as well as the type of salt or the mineral, and not only the TDS (Squires, 1993; Valtorta et al., 2008). All the examined waters in the present study presented high $\mathrm{Cl}$ levels, considering the potential water intake of a lamb weighting 20 and showing $100 \mathrm{~g}$ /day of weight gain. The sodium supply through the brackish waters is also elevated compared to the daily requirements of this animal. Beede (2012) does not indicate maximum tolerable levels of $\mathrm{Cl}$ in the drinking water, but suggests $300 \mathrm{mg} / \mathrm{L}$ of chlorides (an ionic form of $\mathrm{Cl}$ ). The average $\mathrm{Cl}$ levels in the water of drilled wells $(1.010 \mathrm{mg} / \mathrm{L})$ ranged from 350 to $2.580 \mathrm{mg} / \mathrm{L}$.

In the case of $\mathrm{Na}$, Beede (2012) suggests $300 \mathrm{mg} / \mathrm{L}$ as the maximum level which is higher than the average obtained in nine out of ten water samples. Only one of the samples showed more than $300 \mathrm{mg} / \mathrm{L}$ of sodium. For young ruminants (veal calves), Beede (2012) suggests significantly lower Na levels (20 mg/L) because this category can be less tolerant to sodium.

Sodium chloride is considered the main component of TDS, apart from other salts or elements that also contribute to TDS (NRC, 2001). In animal nutrition, sodium and chlorine are considered jointly and, on average, sodium levels found were high, representing $82.80 \%$ of mineral requirements of a lamb weighting $20 \mathrm{~kg}$. Chlorine also 
showed high concentration, with a potential contribution to the animal that exceeds the daily requirements, especially when considering the waters with larger concentrations.

The excess of $\mathrm{NaCl}$ in the water can reduce feed intake and increase intake of water (Peirce, 1957; Wilson \& Dudzinski, 1973). Increase in milk production (Solomon et al., 1995) and greater efficiency in milk production (Guadalupe et al., 2015) were observed in lactating cows receiving water desalinated compared to saline water. However, saline water has been used in domestic ruminants without health damage reports (Kii \& Dryden, 2005; Valtorta et al., 2008; Visscher et al., 2013). According to Peirce (1957), Wilson (1975) and Squires (1993), 1.0 to $1.2 \%$ of $\mathrm{NaCl}$ in the water ( 10 to $12 \mathrm{~g} / 1.000 \mathrm{~g}$ of the solution) does not cause health damages to the animals.

According to $\mathrm{NRC}$ (2005), it is described $\mathrm{NaCl}$ toxicity from intake of $4.0 \%$ of DM, corresponding to $25.20 \mathrm{~g} / \mathrm{day}$ for an animal eating $630 \mathrm{~g} /$ day of DM. Considering a daily water intake of $1.44 \mathrm{~L}$ and the average concentration observed in the current study, the $\mathrm{NaCl}$ intake through water would be $1.79 \mathrm{~g} / \mathrm{day}$, which are below the toxic level.

Considering each analyzed element and considering a growing ovine with $20 \mathrm{~kg}$ of body weight, showing 100 $\mathrm{g}$ /day of weight gain and presenting macro minerals requirements of (g/day) $1.50 \mathrm{P} ; 2.90 \mathrm{~K} ; 2.30 \mathrm{Ca} ; 0.60 \mathrm{Mg}$; $1.10 \mathrm{~S} ; 0.40 \mathrm{Na}$ and $0.30 \mathrm{Cl}$ (NRC, 2007) and an estimated water intake of $1.44 \mathrm{~L} /$ day $(\mathrm{NRC}, 2007)$, the daily supply based on the average levels of the analyzed water of drilled wells would be $<0.01 \%,<1.0 \% ; 15.03 \%$; $64.80 \% ; 13.00 \% ; 81.80 \%$ and $>100.00 \%$, respectively. Phosphorus and $\mathrm{K}$ showed a low potential of being supplied by water while $\mathrm{Cl}, \mathrm{Na}$ and $\mathrm{Mg}$ presented a considerable potential to be supplied by water.

Brum and Sousa (1985) examined the mineral composition of drinking water for bovines and found low contribution, below $1 \%$ of the daily requirements of cows for $\mathrm{Ca} ; \mathrm{P} ; \mathrm{Mg} ; \mathrm{Cu}$; $\mathrm{Co}$ and $\mathrm{Zn}$. On the other hand, the contribution of $\mathrm{K}$ and $\mathrm{Fe}$ was $9.27 \%$ and $16.64 \%$, respectively. In the case of $\mathrm{Na}$, the contribution of saline water, considering a daily intake of $26 \mathrm{~L}$ /day would meet $209.73 \%$ of Na requirements, which may affect mineral mix intake.

Phosphorus causes environmental worries because, in water, in the form of $\mathrm{PO}_{4}$, can promote eutrophication (Hubbard et al., 2004). Sinclair and Atkins (2015) identified an excess of phosphorus in the diet as one of the main mineral contaminants on dairy farms. Castillo et al. (2013) verified that high mineral concentration in the water may increase the supply to the animals and consequently in the waste, and according to these authors when the objective is to reduce mineral excretions in waste, it is important to consider the water supply.

Supplementing P through water is one of the strategies to supply this element to ruminants (Karn, 2001), especially when soluble phosphorous are used. The supply of minerals to animals is done through intake of feed, water and soils. According to Duarte et al. (2011) in Brazil, the deficiency of P is the most important among the minerals, resulting in reproductive disorders and reduction in the productive performance. In addition, Prasad et al. (2015) reported that $\mathrm{P}$ deficiency can promote bone disorders and weakness in the animals.

Calcium, magnesium, sulphur, sodium and chlorine may be supplied considerably through water wells. In the case of $\mathrm{Ca}$, two of the analyzed water showed 450 and $510 \mathrm{mg} / \mathrm{L}$, which could supply $28.17 \%$ and $31.93 \%$ of the daily requirements for an ovine of $20 \mathrm{~kg}$ with a weight. Considering a diet insufficient to provide mineral to animals, the intake of water can be favorable to complement the supply of minerals. However, when the diet is sufficient to provide minerals as reported by Tebaldi et al. (2000), the excessive supply of a particular element may cause antagonistic or toxic effects.

Beede (2012) proposed $200 \mathrm{mg} / \mathrm{L}$ of Ca as the upper limit in the drinking water for livestock farming. Five of the ten water samples showed Ca concentration below $200 \mathrm{mg} / \mathrm{L}$ while only one exceeded $500 \mathrm{mg} / \mathrm{L}$. The maximum level of $\mathrm{Ca}$ in the diet is $1.50 \%$ of DM (NRC, 2005). Considering a lamb with an intake of $630 \mathrm{~g}$ DM/day, the daily $\mathrm{Ca}$ intake would be $9.45 \mathrm{~g} /$ day. The estimated water intake in the current study was $1.44 \mathrm{~L} /$ day, so the lamb could receive $0.35 \mathrm{~g} /$ day of $\mathrm{Ca}$, which leaves a considerable amount of $\mathrm{Ca}$ to be supplied through the diet. Calcium is the main structural component of bones and teeth and its deficiency can cause rickets in young animals, osteomalacia in adults and milk fever in lactating animals. On the other hand, according to McDowell (1989), the excess can cause hypercalcemia or calcification of body tissues.

The highest concentration of $\mathrm{Ca}$ compared to the $\mathrm{P}$ promoted high $\mathrm{Ca}: \mathrm{P}$ ratio in the drinking water. According to NRC (2007) the ideal $\mathrm{Ca}: \mathrm{P}$ is described in the order of 2:1. In the analyzed water samples was 3:1 on average and one sample showed 51:1 of Ca:P. The imbalances in $\mathrm{Ca}: \mathrm{P}$ can affect mineral absorption.

High levels of $\mathrm{Mg}$ were observed in the water of drilled wells. The water samples with greater $\mathrm{Mg}$ concentration $(420 ; 540$ and $660 \mathrm{mg} / \mathrm{L})$ has potential to provide the requirements of a lamb and those with lower Mg levels (80 $\mathrm{mg} / \mathrm{L})$ showed considerable potential to contribute to the animal. 
The Australian Water Resources Council (AWRC) (1969) and Ayers and Westcott (1994) suggested 250 to 500 $\mathrm{mg} / \mathrm{L}$, depending on the category and physiological state of the animal, as the maximum limits for the concentration of $\mathrm{Mg}$ in drinking water for ruminants. The average $\mathrm{Mg}$ level $(270 \mathrm{mg} / \mathrm{L})$ is higher the limits for lactating animals $(250 \mathrm{mg} / \mathrm{L})$. Two water samples showed $\mathrm{Mg}$ higher than $500 \mathrm{mg} / \mathrm{L}$, which are above the recommendation. Beede (2012) suggested 100 and $<125 \mathrm{mg} / \mathrm{L}$ of $\mathrm{Mg}$ in the water as the maximum limit to be allowed for livestock farming and for bovines, respectively. Therefore, only two samples $(80 \mathrm{mg} / \mathrm{L})$ would be safe to the animals.

The negative effects of high levels of $\mathrm{Mg}$ are the possible restriction in feed intake and diarrhea (NRC, 2001). Fasae and Omolaha (2014) examined Mg levels in the drinking water for ruminants, verified that concentration of this mineral was slightly above the recommended $(30 \mathrm{mg} / \mathrm{L})$ and reported possible aesthetic problems. According to NRC (2001), water samples containing $0-60 \mathrm{mg} / \mathrm{L}$ of $\mathrm{Ca}$ and $\mathrm{Mg}$ are considered light, from 61 to $120 \mathrm{mg} / \mathrm{L}$ are considered moderately hard, with 121 to $180 \mathrm{mg} / \mathrm{L}$ hard and containing more than $180 \mathrm{mg} / \mathrm{L}$ very hard, but, on the other hand, hardness of water up to $290 \mathrm{mg} / \mathrm{L}$ was not associated with ruminant disorders.

High concentrations of $\mathrm{Mg}$ can also affect the absorption of other minerals such as $\mathrm{P}$, as well as an excess of $\mathrm{P}$ and $\mathrm{K}$ can affect the absorption and metabolism of Mg (NRC, 2001). Magnesium levels above $0.60 \%$ of DM in the diet are considered as the maximum level of the daily intake, which may promote intoxication and cause urolithiasis, lethargy, diarrhea, reduction in feed intake and reduce the productive performance (NRC, 2007).

In the case of $\mathrm{K}$, the percentage of the nutritional requirements potentially supplied by water would be low, lower than $1.0 \%$ for a growing sheep. Potassium levels varied from 10 to $20 \mathrm{mg} / \mathrm{L}$ in the water samples. All the water samples are within the maximum limits suggested by Beede (2012) for use in livestock farming. Potassium deficiency can promote reduction in growth, production and in feed intake (Puls, 1994).

Potassium is also important in the peripartum of lactating animals, especially those showing elevated milk production. In this phase, the animals are more susceptible to metabolic and nutritional disorders such as hypocalcemia and retained placenta (Greghi et al., 2014). A method to reduce hypocalcemia is to supply anionic diets promoting a negative cation-anion balance (Wilkens et al., 2012), which is calculated by the sum of $\mathrm{K}^{+}$and $\mathrm{Na}^{+}$subtracting the sum of $\mathrm{Cl}^{-}$and $\mathrm{S}^{2-}$ in order to increase $\mathrm{Ca}$ absorption.

The potential contribution of water is considerable for $\mathrm{S}$, in order to $26.08 \%$ in the sample with the highest concentration $(200 \mathrm{mg} / \mathrm{L})$. Beede (2012) does not give any recommendations for maximum limits of $\mathrm{S}$, but suggested $300 \mathrm{mg} / \mathrm{L}$ of sulfate $\left(\mathrm{SO}_{4}\right)$ for use in livestock farming. Wright (2007) reported $1.000 \mathrm{~g} / \mathrm{L}$ as a safe sulfate level but above $4.000 \mathrm{mg} / \mathrm{L}$ it can be potentially toxic. In all water samples S levels were below $200 \mathrm{mg} / \mathrm{L}$, suggesting low concentration of $\mathrm{SO}_{4}$, below $300 \mathrm{mg} / \mathrm{L}$, which does not restrict the water intake.

High sulfate concentration may reduce water intake (Beede, 2006). According to Lardner et al. (2013) animals did not choose treated waters and preferred non-treated waters from wells with TDS $<3,000 \mathrm{mg} / \mathrm{L}$ and $\mathrm{SO}_{4}<2,000$ $\mathrm{mg} / \mathrm{L}$. Sulfate levels of over $2.000 \mathrm{mg} / \mathrm{L}$ in the drinking water negatively influenced the animals' intake.

Beke and Hironaka (1991) reported the occurrence of poliencephalomalacia in Hereford calves receiving saline water with predominance of $\mathrm{Na}$ and $\mathrm{S}$, suggesting that the elevated intake of $\mathrm{S}$ as the causative agent. In the diet, the maximum tolerable $\mathrm{S}$ level is $0.30 \%$ of DM (NRC, 2005) when the animals are fed with concentrated ingredients.

In the case of trace minerals, Fe showed the highest concentration in the analyzed water samples with $1.36 \mathrm{mg} / \mathrm{L}$, with a large variation, followed by $\mathrm{Mn}, \mathrm{Pb}, \mathrm{Ni}, \mathrm{Zn}, \mathrm{Cr}$ and $\mathrm{Cu}$, which averaged $0.27,0.10,0.08,0.07,0.04$ and 0.04 $\mathrm{mg} / \mathrm{L}$. (Table 2). The potential contribution of water for a lamb with a body weight of $20 \mathrm{~kg}$ for Fe, $\mathrm{Mn}, \mathrm{Cu}$ and $\mathrm{Zn}$ would be low, on average, $6.12 \%, 3.24 \%, 1.86 \%$ and $0.78 \%$, respectively. The water sample with $0.23 \mathrm{mg} / \mathrm{L}$ of Cu has a potential to contribute to $10.68 \%$ of the daily requirements of a growing sheep.

The AWRC (1969), Ayers and Westcott (1994) and Beede (2012) suggest $0.50 \mathrm{mg} / \mathrm{L}$ as the maximum limit of Cu in drinking water for ruminants. The concentrations of $\mathrm{Cu}$ in all the water samples were below $0.50 \mathrm{mg} / \mathrm{L}$. In nine of the ten analyzed samples, the concentrations of $\mathrm{Cu}$ did not exceed $0.03 \mathrm{mg} / \mathrm{L}$, but in one of them, the concentration of $\mathrm{Cu}$ was $0.23 \mathrm{mg} / \mathrm{L}$.

Copper is important to the animal as part of the enzymatic systems and its deficiency can cause anemia. The maximum tolerable level of $\mathrm{Cu}$ for a lamb is $15 \mathrm{mg} / \mathrm{kg}$ of DM when diets with normal concentrations of Mo (1 to 2 $\mathrm{mg} / \mathrm{kg}$ of DM) and $\mathrm{S}(0.15 \%$ to $0.25 \%)$ are offered. Goats may have greater tolerance than sheep, while for cattle $40 \mathrm{mg} / \mathrm{kg}$ of DM is used as the maximum tolerable level. The minerals $\mathrm{Cu}, \mathrm{Mo}, \mathrm{S}$ and Fe should be considered jointly for the animal because the availability of $\mathrm{Cu}$ is reduced in the presence of the other three elements (NRC, 2005). According to Mohammed et al. (2014) $\mathrm{Cu}$ and $\mathrm{P}$ are the main limiting minerals for grazing ruminants in 
Asia, Africa and Latin America and copper deficiency can cause growth reduction, bone disorders, diarrhea and infertility. The relationship between trace minerals is important to the absorption of minerals and according to Marques et al. (2013), increased levels of $\mathrm{Fe}, \mathrm{Mn}$ and $\mathrm{Zn}$ limit absorption of $\mathrm{Cu}$.

The water sample with greater Fe may contribute on the level of $50.40 \%$, in the matter of the daily requirements of lamb with a body weight of $20 \mathrm{~kg}$. Iron is the most abundant trace mineral of the body and constituent of hemoglobin. In addition, elevated intake of $\mathrm{Fe}$ can promote $\mathrm{Cu}$ deficiency in sheep and goats, with the maximum tolerable level of $500 \mathrm{mg} / \mathrm{kg}$ of DM (NRC, 2005). In other words, the observed levels in the water are well below the concentrations of Fe considered toxic. In Brazil, Fe has not been identified as a deficient mineral for ruminants, due to the production system based and tropical pastures (Peixoto et al., 2005; Malafaia et al., 2014).

Beede (2006) reported that Fe levels over $0.30 \mathrm{mg} / \mathrm{L}$ can reduce water feed intake by the animals and may also promote the proliferation of microorganisms, contributing to mud formation and affect the flux of water in tubing. The predominant form of $\mathrm{Fe}$ in the water is important for mineral nutrition because the ferrous form $\left(\mathrm{Fe}^{2+}\right)$ is soluble in water compared to the ferric form $\left(\mathrm{Fe}^{3+}\right)$, which is present in the food. The highly soluble iron can interfere in the absorption of $\mathrm{Cu}$ and $\mathrm{Zn}$. In the current study, the presented values corresponded to total Fe. Four of the ten water samples showed Fe levels above $0.30 \mathrm{mg} / \mathrm{L}$. One water sample showed $11.20 \mathrm{mg} / \mathrm{L}$ of $\mathrm{Fe}$, much higher than the maximum suggested which may cause rejection of water. Al-Khaze'leh et al. (2015) examined water quality for goats in Jordan and also found high levels of Fe.

Genther and Beede (2013) examined the water intake, preference and behavior of dairy cows receiving water with different concentrations, valences and sources of Fe, supplying 0,4 and $8 \mathrm{mg} / \mathrm{L}$ in the form of ferrous lactate. These authors observed that cows spent less time ingesting water with $8 \mathrm{mg} / \mathrm{L}$ of Fe in comparison to the other waters. They also observed that the cows' preference was not affected by the sources of $\mathrm{P}$ nor by the valences.

Table 2. Trace mineral concentration $(\mathrm{mg} / \mathrm{L})$ of the water from drilled wells in the Brazilian semi-arid

\begin{tabular}{|c|c|c|c|c|c|c|c|c|}
\hline Sample & $\mathrm{Cu}$ & $\mathrm{Fe}$ & $\mathrm{Mn}$ & $\mathrm{Zn}$ & $\mathrm{Ni}$ & $\mathrm{Cd}$ & $\mathrm{Pb}$ & $\mathrm{Cr}$ \\
\hline 1 & 0.01 & 0.14 & 0.04 & 0.08 & 0.09 & 0.01 & 0.01 & 0.03 \\
\hline 2 & 0.03 & 0.92 & 0.01 & 0.06 & 0.08 & 0.01 & 0.03 & 0.06 \\
\hline 3 & 0.23 & 0.19 & 0.06 & 0.25 & 0.10 & 0.00 & 0.22 & 0.05 \\
\hline 4 & 0.01 & 11.2 & 2.18 & 0.07 & 0.15 & 0.00 & 0.10 & 0.05 \\
\hline 5 & 0.01 & 0.11 & 0.10 & 0.06 & 0.16 & 0.00 & 0.24 & 0.06 \\
\hline 6 & 0.01 & 0.06 & 0.18 & 0.06 & 0.11 & 0.01 & 0.09 & 0.03 \\
\hline 7 & 0.02 & 0.05 & 0.03 & 0.03 & 0.11 & 0.00 & 0.09 & 0.04 \\
\hline 8 & 0.01 & 0.06 & 0.02 & 0.04 & 0.05 & 0.00 & 0.11 & 0.04 \\
\hline 9 & 0.02 & 0.42 & 0.03 & 0.02 & 0.00 & 0.06 & 0.01 & 0.00 \\
\hline 10 & 0.01 & 0.44 & 0.04 & 0.02 & 0.00 & 0.08 & 0.00 & 0.04 \\
\hline Mean & 0.04 & 1.36 & 0.27 & 0.07 & 0.08 & 0.02 & 0.10 & 0.04 \\
\hline $\mathrm{SD}$ & 0.07 & 3.48 & 0.67 & 0.07 & 0.05 & 0.03 & 0.08 & 0.02 \\
\hline Guidelines $^{\mathrm{a}}$ & 0.50 & 0.40 & 0.50 & 25.00 & 1.00 & 0.05 & 0.10 & 1.00 \\
\hline Guidelines $^{\mathrm{b}}$ & $>0.60$ to 1.00 & $>0.30$ & $>0.05$ & $>25.00$ & -1 & $>0.05$ & $>0.10$ & -1 \\
\hline
\end{tabular}

Note. $\mathrm{Mo}^{*}=$ molybdenum; $\mathrm{Co}^{*}=$ cobalt $; \mathrm{Cu}=$ copper; $\mathrm{Fe}=$ iron; $\mathrm{Mn}=$ manganese $\mathrm{Zn}=$ zinc; $\mathrm{Ni}=$ nickel; $\mathrm{Cd}=$ Cadmium; $\mathrm{Pb}=$ Lead; $\mathrm{Cr}=$ chromium; $\mathrm{SD}=$ standard deviation; ${ }^{\mathrm{a}, \mathrm{b}}$ Beede $(2012)\left({ }^{\mathrm{a}}\right.$ : concentrations above which problems likely could occur in livestock; ${ }^{\text {b }}$ : possible cattle problems); ${ }^{1}$ : non presented.

Water samples with high levels of Mn may contribute on the level of $26.16 \%$, when it comes to of the daily requirements for a growing sheep. According to Zhang et al. (2014), $\mathrm{Mn}$ is an essential trace element related to the organic matrix, a cofactor for important enzymes and is also involved in the amino acid metabolism. According to NRC (2007), Mn is described as being slightly toxic to ruminants even at high levels, but can promote antagonism between Mn and Fe. According to NRC (2005), the maximum tolerable level of Mn is $2.000 \mathrm{mg} / \mathrm{kg}$ of DM.

In drinking water for ruminants, Ayers and Westcott (1994), Runyan and Bader (1994) and Beede (2012) suggest that $0.05 \mathrm{mg} / \mathrm{L}$ of $\mathrm{Mn}$ is the maximum limit for domestic animals. Four water samples presented $\mathrm{Mn}$ concentrations above this recommendation. According to Beede (2012), concentrations above $0.05 \mathrm{mg} / \mathrm{L}$ of $\mathrm{Mn}$ 
affect water intake. Pérez-Carrera et al. (2007) found that $12.50 \%$ and $92 \%$ of water samples from water table and deep wells, respectively in dairy production systems in Argentina, showed Mn levels above 0.05 mg/L.

The $\mathrm{Zn}$ concentrations observed in all water samples were low in relation to the daily requirements of lambs. The water sample containing the highest concentration would supply $2.77 \%$ of the daily requirement of a lamb with a body weight of $20 \mathrm{~kg}$. Zinc is involved in the composition of many enzymes that participate in various metabolic pathways and its deficiency can cause reproductive and skeletal disorders, skin and wool anomalies and anorexia (NRC, 2007). Ruminants can tolerate higher levels of $\mathrm{Zn}$ than non-ruminants. For sheep, the maximum tolerable level is $300 \mathrm{mg} / \mathrm{kg}$ of DM (NRC, 2005). Ten water samples showed $\mathrm{Zn}$ levels below $25 \mathrm{mg} / \mathrm{L}$, suggested as the maximum tolerable (Beede, 2012). Smith (1980) examined the addition of zinc sulfate to drinking water for bovines $(0.25,0.50$ and $1.0 \mathrm{~g} / \mathrm{L}$ of $\mathrm{Zn})$ and found a reduction in water intake by $8.0 \%, 35.0 \%$ and $54 \%$, respectively, compared to the animals receiving water without the addition of $\mathrm{Zn}$.

The average levels of $\mathrm{Ni}, \mathrm{Cd}$ and $\mathrm{Cr}$ were below the maximum level suggested by Beede (2012), in the order of $1.00,0.05$ and $1.00 \mathrm{mg} / \mathrm{L}$, respectively, while the concentration of $\mathrm{Pb}$ was at the suggested level $(0.10 \mathrm{mg} / \mathrm{L})$. Nickel and $\mathrm{Pb}$ showed higher average levels (Table 2). Chromium and nickel are elements required by the animals. Chromium is associated with stress responses, glucose metabolism and immune response, while nickel is required by the microorganisms of the rumen (NRC, 2007).

In all analyzed water samples the presence of $\mathrm{Ni}$ and $\mathrm{Cr}$ was found in concentrations below $1.00 \mathrm{mg} / \mathrm{L}$. Cadmium levels above $0.05 \mathrm{mg} / \mathrm{L}$ and $\mathrm{Pb}$ above $0.10 \mathrm{mg} / \mathrm{L}$ were observed in two and three water samples, respectively. The average concentration of Cd also was below the limits of $0.05 \mathrm{mg} / \mathrm{L}$ established by the AWRC (1969) and by Ayers and Westcott (1994).

The NRC (2001) is more restrictive to these elements (heavy metals) and for $\mathrm{Ni}, \mathrm{Cd}, \mathrm{Pb}$ and $\mathrm{Cr}$ the suggested upper limits are: $0.25 \mathrm{mg} / \mathrm{L}, 0.005 \mathrm{mg} / \mathrm{L}, 0.105 \mathrm{mg} / \mathrm{L}$ and $0.10 \mathrm{mg} / \mathrm{L}$, respectively. Cadmium and Pb averages observed in the water exceeded the recommended limits. Five of the ten water samples showed concentrations below the suggested levels for $\mathrm{Cd}$ and three for $\mathrm{Pb}$.

Cadmium and $\mathrm{Pb}$ are elements considered toxic to the animals, accumulating in the body. Cadmium can cause renal damages (NRC, 2001) and $\mathrm{Pb}$ may promote hematologic, reproductive, immune, vascular and renal damages (Pareja-Carrera et al., 2014). They are also antagonists of others minerals. Cadmium interferes in the absorption and metabolism of $\mathrm{Zn}$ and $\mathrm{Cu}$, while $\mathrm{Pb}$ affects the absorption and function of $\mathrm{Zn}(\mathrm{NRC}, 2001)$ and the metabolism of $\mathrm{Ca}$ (Pareja-Carrera et al., 2014). In addition, $\mathrm{Ca}, \mathrm{P}, \mathrm{Fe}$ and $\mathrm{Zn}$ can reduce the absorption of $\mathrm{Pb}$ (NRC, 2001).

Valente-Campos et al. (2014) found a great variation in the upper permitted limits of minerals in the water for domestic animals in different countries. Cadmium, for instance, ranged from $0.005 \mathrm{mg} / \mathrm{L}$ to $0.14 \mathrm{mg} / \mathrm{L}$. In Brazil, the presented limits varied from 0.01 to $0.05 \mathrm{mg} / \mathrm{L}$. The multiple recommendations of maximum limit for macro and trace minerals makes difficult the understanding of physical-chemical parameters of the water for animals.

The analyzed water presented levels of TDS and other macro minerals that, in accordance with the presented information are not restricted for domestic ruminants as sheep, goats and cattle. However, its use may be dependent of several factors as animal species and physiological stage. In general, water samples presented heterogeneity in mineral composition with different potential contribution to the animal, but minerals levels can be considered in the animal nutrition, avoiding for example antagonistic effects.

The dilution of drinking water with fresh water or rainwater can contribute to use of saline water. The reduction of evaporation rates of water in the reservoirs is also an important strategy to prevent the increase of mineral in the water. Shirley (1985) reports that the bioavailability of minerals in water is similar to those observed in food. However, the mineral bioavailability in each type of water sample is an important information in order to verify the real potential to supply minerals for domestic ruminants.

Trace minerals were found to be more potentially restrictive in the water samples, especially $\mathrm{Cd}$ and $\mathrm{Pb}$, while $\mathrm{Fe}$ and $\mathrm{Mn}$ were found at levels that can promote a rejection or a reduction in water intake by the animal or interfere in the absorption and metabolism of other mineral. Determination of mineral levels in the water is fundamental to promote a safe use of this natural resource. The spatial and temporal variation in the electric conductivity of subterranean waters in the Brazilian semi-arid region (Andrade et al., 2012) and the physical-chemical characterization of water should be more frequent. Additional research is required to establish the limits of the mineral in the drinking water of domestic ruminants.

\section{Conclusions}

Well waters showed a variation in mineral levels with a predominance of $\mathrm{Cl}, \mathrm{Mg}, \mathrm{Ca}$ and $\mathrm{Na}$ as macro minerals and $\mathrm{Fe}$ and $\mathrm{Mn}$ as trace minerals. The waters showed low levels of $\mathrm{P}$ and consequently presented low 
contribution potential in this mineral, but showed an elevated potential to supply chlorine. Total dissolved solids (TDS) levels in the majority of the samples are within the acceptable range, apart from having the presence of potentially toxic elements such as $\mathrm{Cr}, \mathrm{Cd}$ and $\mathrm{Pb}$ in concentrations above the recommended.

\section{References}

AbouHussien, E. R. M., Gihad, E. A., El-Dedawy, T. M., \& Abdel Gawad, M. H. (1994). Response of camels, sheep and goats to saline water. 2. Water and mineral metabolism. Egyptian Journal of Animal Production, $31,387-401$.

Albuquerque, I. R. R. (2012). Níveis de salinidade da água de beber para ovinos mestiços Santa Inês (Dissertação de Mestrado). Universidade Federal da Paraíba, Paraíba.

Al-Khaze'leh, J. M., Reiber, C., Al Baqain, R., \& Zárate, A. V. (2015). Drinking water sources, availability, quality, access and utilizationfor goats in the Karak Governorate, Jordan. Tropical Animal Health and Production, 47, 163-169. http://dx.doi.org/10.1007/s11250-014-0702-6

Alves, J. N. (2012). Novilhas Sindi submetidas a ingestão de água com diferentes níveis de salinidade (Tese de Doutorado). Universidade Federal da Paraíba, Paraíba.

Araújo, G. G. L., Voltolini, T. V., Chizzotti, M. L., Turco, S. H. N., \& Carvalho, F. F. R. (2010). Water and small ruminant production. Revista Brasileira de Zootecnia, 3, 9326-336. http://dx.doi.org/10.1590/S1516-359 82010001300036

Arjomandfar, M., Zamiri, M. J., Rowghani, E., Khorvash, M., \& Ghorbani, Gh. (2010). Effects of water desalination on milk production and several blood constituents of Holstein cows in a hot arid climate. Iranian Journal of Veterinary Research, 11, 233-238.

Australian Water Reseources Council (AWRC). (1969). Quality aspects of farm water supplies. Canberra, DC: Department of National Development.

Ayers, R. S., \& Westcot, D. W. (1994). Water quality for agricuture.Food and Agriculture. Rome, Italy, DC: Organization of the United Nations.

Bahman, A. M., Rooker, J. A., \& Topps, J. H. (1993). The performance of dairy cows offered drinking water of a low or high salinity in hot arid climate. Animal Production, 57, 23-28. http://dx.doi.org/10.1017/S0003 35600006565

Beede, D. K. (2006). Evaluation of water quality and nutrition for dairy cattle (p. 24). High Plains Dairy Conference.

Beede, D. K. (2012). What will our ruminants drink? Animal Frontiers, 2, 36-43. http://dx.doi.org/10.2527/ af.2012--0040

Beke, G. J., \& Hironaka, R. (1991). Toxicity to beef cattle of sulfur in saline well water: A case study. Science of The Total Environment, 101, 281-290. http://dx.doi.org/10.1016/0048-9697(91)90042-D

Brum, P. A. R. de, \& Sousa, J. C. de. (1985). Níveis de nutrientes minerais para gado, em lagoas ("Baías e Salinas”) no pantanal Sul Mato-grossense. Pesquisa agropecuária Tropical, 20, 1451-1454.

Castillo, A. R., St-Pierre, N. R., Silva del Rio, N., \& Weiss, W. P. (2013). Mineral concentrations in diets, water, and milk and their value in estimating on-farm excretion of manure minerals in lactating dairy cows. Journal of Dairy Science, 96, 3388-3398. http://dx.doi.org/10.3168/jds.2012-6121

Conselho Nacional do Meio Ambiente (CONAMA). (2005). Resolução $n^{\circ} 357$ de 17 de março de 2005. Dispõe sobre a qualidade dos corpos de água e diretrizes ambientais para o seu enquadramento, bem como estabelece as condições e padrões de lançamentos de efluentes e dá outras providências. Diário Oficial da República Federativa do Brasil, Brasília, DF. Retrieved June 16, 2015, from http://www.mma.gov.br/conama/res/res05/res35705.pdf

Costa, S. A. P. (2012). Oferta de água com níveis de salinidade para ovinos Morada Nova (Dissertação de Mestrado). Universidade Federal do Vale do São Francisco, Petrolina, Pernambunco.

Duarte, A. L. L., Pires, M. L. de S., Barbosa, R. R., Dias, R. B. da C., \& Soto-Blanco, B. (2011). Avaliação da deficiência de fósforo em ruminantes por meio de bioquímica sérica. Acta Veterinaria Brasilica, 5, $380-384$.

Fasae, O. A., \& Omolaja, O. E. (2014). Assessment of drinking water quality from different sources in Smallholder ruminant production in Abeokuta, Nigeria. Food Science and Quality Management, 29, 39-43. 
Genther, O. N., \& Beede, D. K. (2013). Preference and drinking behavior of lactating dairy cows offered water with different concentrations, valences, and sources of iron. Journal of Dairy Science, 96, 1164-1176. http://dx.doi.org/10.3168/jds.2012-5877

Greghi, G. F., Netto, A. S., Schalch, U. M., Bonato, C. S., Santana, R. S. S., Cunha, J. A., ... Zanetti, M. A. (2014). Suplemento mineral aniônico para vacas no periparto: Parâmetros sanguíneos, urinários e incidência de patologias de importância na bovinocultura leiteira. Pesquisa Veterinária Brasileira, 34, $337-342$. http://dx.doi.org/10.1590/S0100-736X2014000400007

Guadalupe, G. M. J., Herrera-Monsalvo, C. D., Lara-Bueno, A., López-Ordaz, R., Jaimes-Jaimes, J., \& Ramirez-Valverde, R. (2015). Effects of drinking water desalination on several traits of dairy cows in a mexican semiarid environment. Life Science Journal, 12, 87-93. http://dx.doi.org/10.7537/j.issn.1097-8135

Herdt, H. H., \& Hoff, B. (2011). The use of blood analysis to evaluate trace mineral status in ruminant livestock.Veterinary. Clinics of North America: Food animal Practice, 27, 255-283. http://dx.doi.org/ 10.1016/j.cvfa.2011.02.004

Hubbard, R. K., Newton, G. L., \& Hill, G. M. (2004). Water quality and the grazing animal. Journal of Animal Science, 82, 255-263.

Karn, J. F. (2001). Phosphorus nutrition of grazing cattle: A review. Animal Feed Science and Technology, 89, 133-153. http://dx.doi.org/10.1016/S0377-8401(00)00231-5

Kattnig, R. M., Pordomingo, A. J., Schneberger, A. G., Duff, G. C., \& Wallace, J. D. (1992). Influence of saline water on intake, digesta kinetics, and serum profiles of steers. Journal of Range Management, 45, 514-518. http://dx.doi.org/10.2307/4002562

Kii, W. Y., \& Dryden, G. McL. (2005). Effect of drinking saline water on food and water intake, food digestibility, and nitrogen and mineral balances of rusa deer stags (Cervus timorensisrussa). Animal Science, 8199-105. http://dx.doi.org/10.1079/ASC41070099

Lardner, H. A., Braul, L., Schwartzkopf-Genswein, K., Schwean-Lardner, K., Damiran, D., \& Darambazar, E. (2013). Consumption and drinking behavior of beef cattle offered a choice of several water types. Livestock Science, 157, 577-585. http://dx.doi.org/10.1016/j.livsci.2013.08.016

Malafaia, P., Costa, R. M., Brito, M. F., Peixoto, P. V., Barbosa, J. D., Tokarnia, C. H., \& Döbereiner, J. (2014). Equívocos arraigados no meio pecuário sobre deficiências e suplementação mineral em bovinos no Brasil. Pesquisa Veterinária Brasileira, 34, 244-249. http://dx.doi.org/10.1590/S0100-736X2014000300008

Marques, A. P. L., Botteon, R. C. C. M., Amorim, E. B., \& Botteon, P. T. L. (2013). Deficiência de cobre condicionada a altos teores de zinco, manganês e ferro na região do Medio Paraíba, RJ, Brasil. Semina: Ciências Agrárias, 34, 1293-1300. http://dx.doi.org/10.5433/1679-0359.2013v34n3p1293

Masters, D. G., Benes, S. E., \& Norman, H. C. (2007). Biosaline agriculture for forage and livestock production. Agriculture, Ecosystems and Environment, 119-248. http://dx.doi.org/10.1016/j.agee.2006.08.003

Mcdowell, L. R. (1989). Vitamins in animal nutrition: Comparative aspects to human nutrition (p. 486). San Diego: Academic Press.

McGregor, B. A. (2004). Water quality and provision for goats (p. 19). Australian Government, Rural Industries Research and Development Corporation.

Mendonça Junior, A. F. (2011). Minerais importância de uso na dieta de ruminantes. Agropecuária Científica no Semi-Árido, 7(1), 1-13.

Mohammed, A., Campbell, M., \& Youssef, F. G. (2014). Serum copper and haematological values of sheep of different physiological stages in the dry and wet seasons of Central Trinidad. Veterinary Medicine International, Article ID 972074. http://dx.doi.org/10.1155/2014/972074

National Research Council. (2nd ed.). (2005). Mineral tolerance of animals. Washington, D.C.: National Academic Press.

National Research Council. (7th ed.). (2001). Nutrient requeriments of dairy cattle. Washington, D.C.: National Academic Press.

National Research Council. (7th ed.). (2007). Nutrient requeriments of small ruminants. Washington, D.C.: National Academic Press. 
Nogueira, A. R. A., Souza, G. B. (2005). Tecido vegetal. Manual de laboratórios: Solo, água, nutrição vegetal, nutrição animal e alimentos (p. 334). São Carlos: Embrapa Pecuária Sudeste.

Oliveira, de M., \& Maia, C. E. (1998). Qualidade físico-química da água para irrigação em diferentes aquíferos na área sedimentar do estado do Rio Grande do Norte. Revista Brasileira de Engenharia Agrícola e Ambiental, 2, 17-21. http://dx.doi.org/10.1590/1807-1929/agriambi.v02n01p17-21

Pareja-Carrera, J., Mateo, R., \& Rodríguez-Estival, J. (2014). Lead (Pb) in sheep exposed to mining pollution: Implications for animal and human helath. Ecotoxicologyand Environmental Safety, 108, $210-216$. http://dx.doi.org/10.1016/j.ecoenv.2014.07.014

Peirce, A. W. (1957). Studies on salt tolerance of sheep for sodium chloride in the drinking water. Australian Journal of Agricultural Research, 8, 711-722. http://dx.doi.org/10.1071/AR9630815

Peirce, A. W. (1963). Studies on salt tolerance of sheep. V. The tolerance of sheep for mixtures of sodium chloride, sodium carbonate, and sodium bicarbonate in the drinking water. Australian Journal of Agricultural Research, 14, 815-823. http://dx.doi.org/10.1071/AR9630815

Peixoto, P. V., Malafaia, P., Barbosa, J. D., \& Tokarnia, C. B. (2005). Princípios de suplementação mineral em ruminantes. Pesquisa Veterinária Brasileira, 25(3), 195-200. http://dx.doi.org/10.1590/S0100-736X 2005000300011

Pérez-Carrera, A., Moscuzza, C., Grassi, D., \& Fernández-Cirelli, A. (2007). Composición mineral del agua de bebida en sistemas de producciónlecheraen Córdoba, Argentina. Veterinaria México, 38, 153-164.

Prasad, C. S., Mandal, A. B., Gowda, N. K. S., Sharma, K., Pattanaik, A. K., Tyagi, P. K., \& Elangovan, A. V. (2015). Enhancing phosphorus utilization for better animal production and environment sustainability. Current Science, 108, 1315-1319.

Puls, R. (1994). Mineral levels in animal health diagnostic data (2nd ed.). Clearbrook, Canada: Sherpa International.

Runyan, C., \& Bader, J. (1994). Water quality for livestock and poultry. Water quality for agriculture (p. 186). FAO Irrigation and Drainage Papers No. 29. FAO, Rome.

Shirley, R. L. (1995). Water requirements for grazing ruminants and water as a source of minerals. In L. R. Mcdowell (Ed.), Nutrition of grazing ruminants in warm climates (pp. 182-186). Orlando: Academic Press.

Sinclair, L. A., \& Atkins, N. E. (2015). Intake of selected minerals on commercial dairy herds in central and northern England in comparison with requirements.The Journal of Agricultural Science, 153, 743-752. http://dx.doi.org/10.1017/S0021859614001026

Solomon, R., Miron, J., Ben-Ghedalia, D., \& Zomberg, Z. (1995). Performance of high producing dairy cows offered drinking water of high and low salinity in the Arava Desert. Journal of Dairy Science, 78, 620-624. http://dx.doi.org/10.3168/jds.S0022-0302(95)76672-3

Squires, V. R. (1993). Australian experiences with high salinity diets for sheep. In H. Lieth, \& A. A. Al Masoom (Eds.), Towards the Rational Use of High Salinity Tolerant Plants (Vol. 1). Deliberations about High Salinity Tolerant Plants and Ecosystems (pp. 449-457). Kluwer Academic Publishers, Dordrecht. http://dx.doi.org/ 10.1007/978-94-011-1858-3 46

Tebaldi, F. L. H., Silva, J. F. C., Vasquez, H. M., \& Thibaut, J. T. L. (2000). Composição Mineral das Pastagens das Regiões Norte e Noroeste do Estado do Rio de Janeiro. 1. Cálcio, Fósforo, Magnésio, Potássio, Sódio e Enxofre. Revista Brasileira de Zootecnia, 29, 603-615. http://dx.doi.org/10.1590/S1516-359820000002 00038

Tokarnia, C. H., Dobereiner, J., Moraes, S. S., \& Peixoto, P. V. (1999). Deficiências e desequilíbrios minerais em bovinos e ovinos: Revisão de estudos realizados no Brasil de 1987 a 1998. Pesquisa Veterinária Brasileira, 19, 47-62. http://dx.doi.org/10.1590/S0100-736X1999000200001

Valente-Campos, S., Nascimento, E de S., \& Umbuzeiro, G. de A. (2014). Water quality criteria for livestock watering-A comparison among different regulations. ActaScientiarum.Animal Sciences, 36, 1-10. http://dx.doi.org/10.4025/actascianimsci.v36i1.21853

Valtorta, S. E., Gallardo, M. R., Sbodio, O. A., Revelli, G. R., Arakaki, C., Leva, P. E., ... Tercero, E. J. (2008). Water salinity effects on performance and rumen parameters of lactating grazing Holstein cows. International Journal of Biometeorology, 52, 239-247. http://dx.doi.org/10.1007/s00484-0118-03 
Visscher, C. F., Witzmann, S., Beyerbach, M., \& Kamphues, J. (2013). Watering cattle (young bulls) with brackish water-A hazard due to its salt content? Tierärztliche Praxis Großtiere, 41, 363-370. http://dx.doi.org/ $10.1111 /$ j.1475-2743.1986.tb00700

Wilkens, M. R., Oberheide, I., Schröder, B., Azem, E., Steinberg, W., \& Breves, G. (2012). Influence of the combination on of 25-hydroxyvitamin $\mathrm{D}_{3}$ and a diet negative in cation-anion difference on peripartal calcium homeostasis of dairy cows. Journal of Dairy Science, 95, 151-164. http://dx.doi.org/10.3168/ jds.2011-4342

Wilson, A. D. (1975). Influence of water salinity on sheep performance while grazing on natural grassland and saltbush pastures. Australian Journal of Experimental Agriculture and Animal Husbandry, 15, 760. http://dx.doi.org/ 10.1071/EA9750760

Wilson, A. D., \& Dudzinski, M. L. (1973). Influence of the concentration and volume of saline water on the food intake of sheep, and on their excretion of sodium and water in urine and faeces. Australian Journal of Agriculture Research, 24, 245-256. http://dx.doi.org/ 10.1071//AR9730245

Zhang, H. H., Zhou, N., Zhang, T. T., Bao, K., Xu, C., Song, X. C., \& Li, G. Y. (2014). Effect of different manganese levels on growth performance and $\mathrm{N}$ balance of growing Mink (Neovision vision). Biological Trace Element Research, 160(2), 206-211. http://dx.doi.org/10.1007/s12011-014-0008-6

\section{Copyrights}

Copyright for this article is retained by the author(s), with first publication rights granted to the journal.

This is an open-access article distributed under the terms and conditions of the Creative Commons Attribution license (http://creativecommons.org/licenses/by/4.0/). 